\title{
Postępy w badaniach niedosłuchu uwarunkowanego genetycznie
}

\section{Advances in the study of genetically determined hearing loss}

\author{
Agnieszka Pollak ${ }^{1}$, Urszula Lechowicz ${ }^{1}$, Monika Ołdak ${ }^{1}$, Rafał Płoski ${ }^{2}$ \\ ${ }^{1}$ Instytut Fizjologii i Patologii Słuchu, Światowe Centrum Słuchu, Zakład Genetyki, Warszawa/Kajetany \\ ${ }^{2}$ Warszawski Uniwersytet Medyczny, Zakład Genetyki Medycznej, Warszawa
}

Adres autora: Agnieszka Pollak, Światowe Centrum Słuchu, Zakład Genetyki, ul. Mokra 17, Kajetany, 05-830 Nadarzyn, e-mail: a.pollak@ifps.org.pl

\section{Streszczenie}

\begin{abstract}
Wprowadzenie: Niedosłuch jest najczęstszym upośledzeniem narządów zmysłów u człowieka. W znaczącej liczbie przypadków jego wystąpienie warunkują czynniki genetyczne. Badania genetyczne w dziedzinie niedosłuchu są dostępne od końca lat 90. ubiegłego wieku. Jednak dopiero ostatnie lata przyczyniły się do wzrostu znaczenia testów molekularnych w ocenie klinicznej osób niedosłyszących. W procesie słyszenia uczestniczą produkty ok. 300 różnych genów, co czyni niedosłuch wyjątkowo heterogennym genetycznie. Kompleksowa diagnostyka genetyczna w dziedzinie niedosłuchu stała się możliwa dopiero od niedawna, dzięki niezwykłemu postępowi związanemu z rozwojem nowych technik sekwencjonowania genomowego.
\end{abstract}

Cel pracy: Podsumowanie i przedstawienie najnowszych trendów w diagnostyce niedosłuchu genetycznie uwarunkowanego.

Materiał i metody: Przegląd literatury przedstawiającej zastosowanie technologii sekwencjonowania nowej generacji w diagnostyce niedosłuchu.

Wyniki i wnioski: Sekwencjonowanie nowej generacji staje się potężnym narzędziem do poszukiwania przyczyn chorób niejednorodnych etiologicznie takich jak niedosłuch. Różnorodność dostępnych platform i testów opartych na tej technologii umożliwia dobranie optymalnego algorytmu postępowania w zależności od klinicznego obrazu pacjenta.

Słowa kluczowe: niedosłuch uwarunkowany genetycznie • sekwencjonowanie nowej generacji • diagnostyka molekularna niedosłuchu

\begin{abstract}
Background: Hearing loss is the most common sensory disability in humans of which genetic factors are responsible for a significant number of cases. Genetic studies in the field of hearing loss are available from the end of the 90s of the last century. The last few years have contributed to the growing importance of molecular tests in the clinical evaluation of hearing loss. Approx. 300 different products of various genes participate in the hearing process, making deafness an extremely heterogeneous genetic disease. Comprehensive genetic evaluation in the area of hearing loss became possible recently due to extraordinary advances in the field of next generation sequencing techniques.
\end{abstract}

Aim of the study: Summary of the latest molecular trends in the diagnosis of genetically related hearing loss.

Material and methods: A literature review showing the practical use of next-generation sequencing technologies for the diagnosis of hearing loss.

Results and conclusions: Next-generation sequencing is a powerful tool to search for etiologically heterogeneous causes of diseases such as hearing loss. The variety of platforms and tests based on this technology allows the selection of an optimal algorithm depending on the phenotype of the patient.

Keywords: genetically determined hearing loss $\bullet$ next-generation sequencing $\bullet$ molecular diagnosis of hearing loss 


\section{Wprowadzenie}

Upośledzenie słuchu to problem, z którym boryka się ok. 360 milionów ludzi na świecie (http://www.who.int). $\mathrm{Z}$ uwagi na tak liczne występowanie wadę tę uznaje się za najczęstsze upośledzenie zmysłów u ludzi. Niedosłuch wrodzony obserwuje się u ok. 1 na 500 noworodków [1]. Większość (około 70\%) przypadków wrodzonego, dziedzicznego ubytku słuchu to niedosłuch izolowany (bez innych współwystępujących objawów - ang. Non-Syndromic Hearing Loss, NSHL), pozostałe $30 \%$ stanowią przypadki niedosłuchu występującego łącznie z innymi upośledzeniami, tworzącymi wspólnie tzw. zespół objawów (niedosłuch syndromiczny, ang. Syndromic Hearing Loss, SHL). Za około $80 \%$ przypadków niedosłuchu izolowanego w krajach rozwiniętych odpowiadają czynniki genetyczne. Zazwyczaj dziedziczną głuchotę odróżnia się od niegenetycznych niedosłuchów, analizując historię wystąpienia choroby w rodzinie oraz na podstawie wyników badania przedmiotowego i profili audiologicznych. Ponadto, w celu dywersyfikacji niedosłuchu izolowanego od syndromicznego, wykonuje się inne testy pomocnicze, m.in. obrazowanie kości skroniowej, analizę moczu, badania czynności tarczycy i EKG. Jednak nawet w przypadku dysponowania szerokim panelem badań diagnostycznych i szczegółowym wywiadem arbitralne potwierdzenie środowiskowej lub genetycznej przyczyny wystąpienia niedosłuchu oraz zróżnicowanie pomiędzy izolowaną a syndromiczną postacią tego schorzenia jest trudne, a w wielu przypadkach wręcz niemożliwe. Obecnie uznaje się, iż w przypadku podejrzenia u pacjenta izolowanego niedosłuchu należy, po zebraniu wywiadu lekarskiego oraz wykonaniu badań fizykalnych i analizie audiogramu, wykonać testy genetyczne.

\section{Sekwencjonowanie nowej generacji w niedosłuchu}

Badania genetyczne $\mathrm{w}$ dziedzinie niedosłuchu są dostępne od końca lat 90. ubiegłego wieku. Jednak dopiero w ostatnich latach wzrosło znaczenie testów molekularnych w ocenie klinicznej osób niedosłyszących. Pierwotnie wartości testów genetycznych w dziedzinie niedosłuchu były marginalne, przede wszystkim ze względu na ograniczoną przepustowość techniki sekwencjonowania DNA oraz stosunkowo wysokie koszty takiej diagnostyki, a także z uwagi na znaczną różnorodność genetyczną niedosłuchu. W praktyce badania ograniczone były do analizy $2-3$ genów, w których mutacje są najczęstszą przyczyną niedosłuchu. Należy pamiętać, że w procesie słyszenia uczestniczą produkty ok. 300 różnych genów, co czyni niedosłuch wyjątkowo heterogennym genetycznie, a kompleksowa diagnostyka genetyczna w dziedzinie niedosłuchu stała się możliwa dopiero od niedawna, dzięki niezwykłemu postępowi związanemu z rozwojem nowych technik sekwencjonowania genomowego (ang. Next Generation Sequencing, NGS; Massively Parallel Sequencing, MPS [2]).

Przed erą NGS do analizy wybranych genów stosowano standardowe techniki sekwencjonowania DNA metodą Sangera. Wykorzystanie tej technologii jako klinicznie użytecznego narzędzia diagnostycznego było praktycznie niemożliwe, z uwagi na konieczność analizy około 80 genów zaangażowanych w patogenezę niedosłuchu (http://www. hereditaryhearingloss.org). W przypadku nieznalezienia w nich zmian patogennych należało rozważyć analizę pozostałych ok. 220 genów uczestniczących w procesie przetwarzania dźwięków. W pierwszej kolejności badano gen GJB2, którego mutacje są najczęstszą przyczyną wystąpienia niedosłuchu autosomalnie recesywnego w wielu populacjach świata. Jeżeli nie znaleziono mutacji w GJB2, wytypowanie następnych genów kandydatów było skomplikowane [3]. Sekwencjonowanie kolejno po sobie genów, potencjalnie wywołujących dany typ niedosłuchu u pacjenta, nie było możliwe ze względu na czas wykonywanych analiz oraz znaczne koszty. Badanie dużej liczby wariantów w opisanych genach było możliwe dzięki zastosowaniu innych, nieopartych na sekwencjonowaniu, technologii np. z wykorzystaniem mikromacierzy [4,5]. Metody te nie zapewniały jednak optymalnej skuteczności w identyfikacji przyczyny wystąpienia wady słuchu, ponieważ przeznaczone były wyłącznie dla znanych mutacji w opisanych genach. Osiągnięcie celu, jakim jest opracowanie metody umożliwiającej badanie jednocześnie wszystkich genów zaangażowanych w wystąpienie niesyndromicznego niedosłuchu (rycina 1), stało się realne dopiero po wprowadzeniu technologii NGS [6-8].

Technologia NGS umożliwiła klinicystom i naukowcom jednoczesne i stosunkowo ekonomiczne sekwencjonowanie milionów lub miliardów par zasad DNA. NGS jest szczególnie przydatne $\mathrm{w}$ diagnostyce niedosłuchu $\mathrm{z}$ powodu ekstremalnej różnorodności genetycznej tego schorzenia. Obecnie zidentyfikowano ponad 1200 wariantów zlokalizowanych we wszystkich poznanych genach odpowiedzialnych za wystąpienie niedosłuchu (http://www. deafnessvariationdatabase.org). Jednak dla 102 loci powiązanych $\mathrm{z}$ niedosłuchem zidentyfikowano jedynie ok. 75 genów, co oznacza, że co najmniej $25 \%$ genów powiązanych z głuchotą nie zostało jeszcze odkrytych (http://hereditaryhearingloss.org).

NGS pozwala na przeprowadzenie kompleksowej analizy genetycznej u pacjentów $\mathrm{z}$ niedosłuchem $\mathrm{z}$ uwagi na możliwość sekwencjonowania wszystkich znanych genów jednocześnie, a także ułatwia odkrycie nowych genetycznych przyczyn niedosłuchu. Wraz z identyfikacją nowych genów i dodawaniem ich do kompleksowych platform badań genetycznych wzrasta skuteczność i wykrywalność przyczyn niedosłuchu, z zastosowaniem dedykowanych testów [9].

\section{NGS z użyciem ukierunkowanego wzbogacania}

Obecnie wykonywane są badania całego genomu w celu identyfikacji regionu potencjalnie powiązanego $\mathrm{z}$ chorobą lub sekwencjonowanie każdego genu w regionie uznanym za prawdopodobnie odpowiedzialny za wystąpienie danego schorzenia, dzięki wykorzystaniu ukierunkowanego genomowego wzbogacania (ang. Targeted Genomic Enrichment, TGE). Aby uniknąć tworzenia unikalnych zestawów dla każdego nowo zidentyfikowanego obszaru, stosuje się sekwencjonowanie eksomowe (ang. Whole Exome Sequencing, WES). Skuteczność tego podejścia została potwierdzona przez liczne grupy, które wykonały klasyczną analizę sprzężeń w celu określenia konkretnych regionów geno$\mathrm{mu}$, a następnie przeprowadziły WES na jednym lub więcej chorych osobach w rodzinie, ograniczając analizę danych WES do obszaru zainteresowania. Innym sposobem poszukiwania przyczyn genetycznych wystąpienia danego 
A

Obecny paradygmat

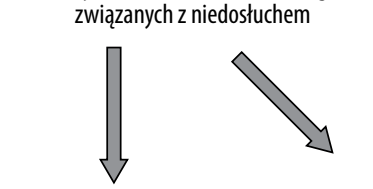

Znalezienie mutacji sprawczej/ych

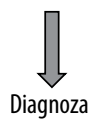

Nie znaleziono mutacji sprawczej

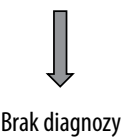

B

Nowe podejście

Jednoczesne sekwencjonowanie WSZYSTKICH genów powiązanych z niedosłuchem

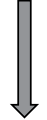

Znalezienie mutacji sprawczej/ych

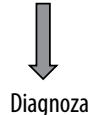

Mutacja nieopisana wcześniej jako powiązana z niedosłuchem

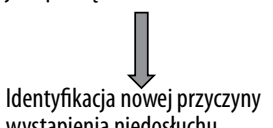
wystąpienia niedosłuchu

Rycina 1. Paradygmat wykonywania badań genetycznych wśród osób niedosłyszących. Schemat A prezentuje sekwencyjne badanie genów, schemat B prezentuje nowe podejście, w którym wszystkie geny są badane jednocześnie

Figure 1. The paradigm of genetic testing of hearing impaired individuals. Scheme $\mathbf{A}$ shows the sequential study of genes. Scheme B presents a new approach in which all genes are tested simultaneously

schorzenia w rodzinach zbyt małych do analizy sprzężeń może być wykonanie WES na kilku osobach dotkniętych chorobą, w celu zidentyfikowania pojedynczej współdzielonej patogennej zmiany.

\section{Panele do analizy genetycznego podłoża niedosłuchu}

Metoda Sangera, polegająca na sekwencjonowaniu kolejno po sobie genów potencjalnie wywołujących dany typ niedosłuchu u pacjenta, nie była wydajna ze względu na czas wykonywanych analiz i ponoszone koszty. Stosowanie podejścia WES jest metodą znacznie skuteczniejszą, aczkolwiek obecnie nadal kosztowną i używaną głównie do celów naukowych. Swoistym kompromisem pomiędzy kosztem badania a jego skutecznością stały się celowane panele obejmujące szereg genów powiązanych $\mathrm{z}$ niedosłuchem.

Pierwsze doniesienie o użyciu NGS do diagnozy NSHL opublikowano w 2010 r. [6]. Zastosowano wówczas ukierunkowane wzbogacanie wybranych regionów genomu - TGE, pokrywające wszystkie eksony znanych genów powiązanych z NSHL, a następnie zsekwencjonowano je z użyciem NGS. Grupa badana składała się z 10 osób, $\mathrm{u}$ trzech $\mathrm{z}$ nich ustalono uprzednio podłoże niedosłuchu, jedna osoba stanowiła kontrolę negatywną (nie miała niedosłuchu), u pozostałych podłoże niedosłuchu nie było znane. W analizowanej grupie dzięki opisywanej technologii postawiono precyzyjną diagnozę dla pięciu pacjentów $\mathrm{z}$ idiopatycznym niedosłuchem. Testowano również czułość i swoistość tej metody w stosunku do stosowanego obecnie standardowego podejścia w badaniach genetycznych - sekwencjonowania metodą Sangera. Czułość wyniosła $99,72 \%$, a swoistość ponad $99 \%$ dla przebadanych 605 polimorfizmów pojedynczych nukleotydów (ang. Single Nucleotide Polymorphism, SNP). Z użyciem opisywanego panelu zidentyfikowano również duże i małe delecje w obrębie badanych genów. Metoda wydaje się obiecująca dla zapewnienia kompleksowej analizy podłoża genetycznie uwarunkowanego niedosłuchu. Panel ten został zaktualizowany i obecnie obejmuje 90 genów powiązanych z niedosłuchem. Oferowany jest jako komercyjny test do stosowania w praktyce klinicznej pod nazwą OtoSCOPE (http://morl-otoscope.org).

W kolejnym badaniu z użyciem TGE i NGS sekwencjonowano jednocześnie 246 genów u każdego z 11 probantów $\mathrm{w}$ celu ustalenia przyczyny genetycznie uwarunkowanego niedosłuchu [7]. Autorzy wybrali 82 ludzkie geny powiązane z SHL i NSHL oraz 162 geny wywołujące niedosłuch u myszy, przyjmując założenie, że włączenie do analizy „mysich” genów głuchoty przyspieszy odkrycie nowych ludzkich genów powiązanych $\mathrm{z}$ wystapieniem niedosłuchu. U jedenastu przebadanych probantów nie znaleziono mutacji w GJB2 i innych genach uważanych za powszechne przyczyny wystapienia genetycznej głuchoty wśród etnicznych grup Arabów palestyńskich oraz Żydów izraelskich. Mutacje powodujące niedosłuch zidentyfikowano u sześciu badanych. Wszystkie wykryte mutacje zlokalizowane były w znanych już genach powiązanych z NSHL. Następnie autorzy poszukiwali analogicznych mutacji wśród innych niesłyszących osób należących do tej samej grupy etnicznej i określili w ten sposób genetyczną przyczynę wystąpienia niedosłuchu dla dalszych 20 rodzin. Analiza ta zdecydowanie podkreśla potencjał TGE i NGS w przypadku kompleksowej diagnostyki genetycznej i w badaniach genów kandydatów, zwłaszcza w jednorodnych etnicznie grupach pacjentów.

W odróżnieniu do opisanych powyżej dwóch metod TGE, w kolejnym badaniu zastosowano odmienne podejście do celowego wychwytywania znanych genów, których mutacje są odpowiedzialne za niedosłuch, $\mathrm{z}$ użyciem innego typu sond. Autorzy potwierdzili skuteczność tej metody dla pięciu genów u pacjentów o ustalonym uprzednio profilu mutacji [10]. Autorzy dokonali również komercjalizacji tej platformy, jako metody służącej do badania genów powiązanych z głuchotą. Dzięki temu podejściu stworzono 
Tabela 1. Komercyjne panele oparte na technologii NGS

Table 1. Commercial panels based on the NGS technology

\begin{tabular}{|c|c|c|c|}
\hline Nazwa testu & $\begin{array}{l}\text { Liczba } \\
\text { analizowanych } \\
\text { genów }\end{array}$ & Technologia & Firma \\
\hline Human Deafness Panel & 129 & Illumina sequencing (MiSeq) & $\begin{array}{l}\text { Otogenetics Corporation, } \\
\text { Norcross, GA, USA }\end{array}$ \\
\hline OtoSCOPE & 90 & $\begin{array}{l}\text { Roche } 454 \text { GS FLX; } \\
\text { Illumina sequencing (GAII) }\end{array}$ & $\begin{array}{l}\text { University of lowa Hospital } \\
\text { and Clinics, Molecular } \\
\text { Otolaryngology and Renal } \\
\text { Research Laboratories, Iowa } \\
\text { City, IA, USA }\end{array}$ \\
\hline Hearing Loss/Deafness Multi-Gene Panel & 76 & $\begin{array}{l}\text { Illumina sequencing (HiSeq, } \\
\text { MiSeq) }\end{array}$ & $\begin{array}{l}\text { Asper Biotech Ltd., Tartu, } \\
\text { Estonia }\end{array}$ \\
\hline OtoGenome Panel & 70 & Illumina sequencing & $\begin{array}{l}\text { Partners HealthCare } \\
\text { Personalized Medicine, } \\
\text { Laboratory for Molecular } \\
\text { Medicine, Cambridge, MA, USA }\end{array}$ \\
\hline OTOGeneProfile67 & 67 & ABI SOLiD sequencing & $\begin{array}{l}\text { Sistemas Genomicos, Medical } \\
\text { Genetics Unit, Paterna, Spain }\end{array}$ \\
\hline Expanded Hearing Loss Panel & 56 & Illumina sequencing (HiSeq) & $\begin{array}{l}\text { ARUP Laboratories, Molecular } \\
\text { Genetics Laboratory, Salt Lake } \\
\text { City, UT, USA }\end{array}$ \\
\hline $\begin{array}{l}\text { Nonsyndromic Hearing Loss } \\
\text { and Deafness NGS Panel }\end{array}$ & 48 & Illumina sequencing & $\begin{array}{l}\text { Prevention Genetics, Clinical } \\
\text { DNA Testing and DNA Banking, } \\
\text { Marshfield, WI, USA }\end{array}$ \\
\hline $\begin{array}{l}\text { Deafness, non-syndromic sensorineural } \\
\text { autosomal recessive panel }\end{array}$ & 44 & \multirow{2}{*}{$\begin{array}{l}\text { Roche } 454 \text { GS Junior; } \\
\text { Life Technologies Ion Torrent } \\
\text { sequencing }\end{array}$} & \multirow[t]{2}{*}{$\begin{array}{l}\text { Centogene AG, Rostock, } \\
\text { Germany }\end{array}$} \\
\hline $\begin{array}{l}\text { Deafness, non-syndromic sensorineural } \\
\text { autosomal dominant panel }\end{array}$ & 32 & & \\
\hline Hearing Loss/Deafness Multi-Gene Panel & 42 & $\begin{array}{l}\text { Illumina sequencing (HiSeq, } \\
\text { MiSeq, GAII); } \\
\text { Life Technologies Ion Torrent } \\
\text { sequencing; } \\
\text { Roche } 454 \text { GS Junior, Roche } \\
454 \text { GS FLX; }\end{array}$ & $\begin{array}{l}\text { Center for Human Genetics } \\
\text { and Laboratory Medicine } \\
\text { Martinsried, Martinsried, } \\
\text { Germany }\end{array}$ \\
\hline OtoSeq Hearing Loss Panel & 23 & Illumina sequencing (HiSeq) & $\begin{array}{l}\text { Cincinnati Children's Hospital } \\
\text { Medical Center, Molecular } \\
\text { Genetics Laboratory, } \\
\text { Cincinnati, OH, USA }\end{array}$ \\
\hline
\end{tabular}

ekonomiczny test przesiewowy dla genetycznie uwarunkowanego niedosłuchu, wysoce konfigurowalny i elastyczny w przypadku odkrycia nowych genów. Platforma ta oferowanej jest przez OtoGenetics (http://www.otogenetics. com) i zawiera 129 genów powiązanych $\mathrm{z}$ niedosłuchem.

\section{Komercyjne platformy oparte na technologii NGS}

Aktualnie dostępnych jest ponad 90 różnych komercyjnych testów opartych na NGS o ogromnej różnorodności zarówno pod względem badanych genów powiązanych z niedosłuchem, jak i zastosowanych technologii. Najważniejsze $\mathrm{z}$ nich przedstawiono w tabeli 1 . Komercyjne panele oparte na technologii NGS, takie jak OtoSCOPE (Otological Sequence Capture of Pathogenic Exons), opracowany przez Uniwersytet Iowa ( $w w w$.healthcare.uiowa.edu) labs/morl/), i OtoGenome Test (http://pcpgm.partners.org/ $\mathrm{lmm} /$ tests/hearing-loss/OtoGenome) umożliwiają stosunkowo szybkie i tanie wykrycie wariantów w znanych ludzkich genach powiązanych $\mathrm{z}$ niedosłuchem.

\section{Potencjalne wielogenowe dziedziczenie niedosłuchu}

Badania nad innymi heterogenicznymi chorobami, takimi jak niepełnosprawność intelektualna czy zwyrodnienie plamki żółtej, pozwoliły na odkrycie ich złożonej zmienności oraz obecności niezwykle ciekawego zjawiska kumulacji rzadkich, szkodliwych wariantów u badanych chorych w porównaniu z populacją kontrolną i grupą pacjentów o niezdiagnozowanym podłożu schorzenia (rycina 2) [1113]. Zgodnie z kilkoma badaniami sugerującymi możliwy wielogenowy sposób dziedziczenia niedosłuchu [14,15], koncepcja kumulacji mutacji obciążających (ang. mutational load), rozproszonych w wielu genach [16], utrudniających prawidłowe funkcjonowanie procesów słuchowych, jest interesującym poglądem w obszarze poszukiwania zaburzeń sprawczych $\mathrm{w}$ niedosłuchu. $\mathrm{Z}$ uwagi na znaczną liczbę genów zaangażowanych w proces słyszenia ta teoria wydaje się obiecująca, a sama częstość występowania rzadkich alleli może służyć jako czynnik prognostyczny o znaczeniu funkcjonalnym [16]. 


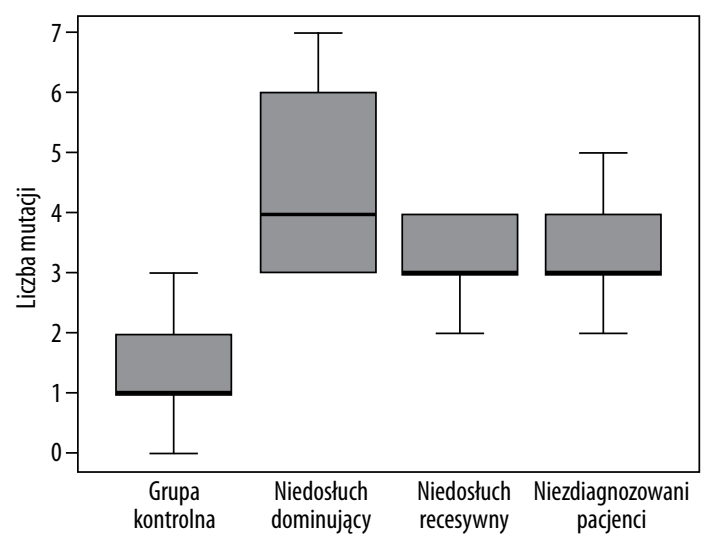

Rycina 2. Dystrybucja wariantów w grupach: kontrolnej oraz wśród pacjentów z niedosłuchem. Średnia liczba wariantów w grupie kontrolnej wynosita 1, natomiast średnia w grupie pacjentów o dominującym typie niedosłuchu wynosiła 4, w grupie pacjentów $z$ niedosłuchem o recesywnym typie dziedziczenia i wśród pacjentów o niezdiagnozowanej przyczynie niedosłuchu 3. Zmodyfikowane na podstawie [18]

Figure 2. The distribution of variants in the groups: control and among patients with hearing impairment. The average number of variants in the control group was 1 , while the average in the group of patients with a dominant type of hearing loss was 4 and in patients with hearing loss of recessive type of inheritance and among patients with undiagnosed cause of hearing loss was 3. Modified from [18]

Ewolucyjne modele genetyczne przewidują występowanie takiego skumulowanego efektu rzadkich, potencjalnie patogennych, rozrzuconych po genomie wariantów, zwiększających podatność na wystąpienie choroby $[16,17]$. Obserwacje poczynione przez Vona i wsp. sugerują, że u osób o niezdiagnozowanej przyczynie niedosłuchu częściej występowały szkodliwe warianty genów powiązanych $\mathrm{z}$ niedosłuchem niż u badanych z grupy kontrolnej, co może potwierdzać tę hipotezę. W takim wypadku można sugerować wielogenowo i wieloczynnikowo uwarunkowane formy dziedziczenia $\mathrm{w}$ niezdiagnozowanej grupie pacjentów, przy czym wpływ uwarunkowań genetycznych $\mathrm{w}$ połączeniu $\mathrm{z}$ innymi niekorzystnymi czynnikami genetycznymi i środowiskowymi może przekroczyć próg krytyczny i powodować manifestację danego fenotypu. Jednocześnie nie można wykluczyć, że zwiększenie liczby wariantów szkodliwych u niezdiagnozowanych probantów jest przypadkowe lub też niedosłuch w niezdiagnozowanej grupie pacjentów był jednak monogeniczną formą głuchoty, ale wywołaną przez wystąpienie wariantów $\mathrm{w}$ niezidentyfikowanych genach.

\section{Podsumowanie}

Identyfikacja nowych genów została znacznie przyspieszona wraz $\mathrm{z}$ wprowadzeniem technologii sekwencjonowania nowej generacji. Tradycyjne metody ustalania genetycznego podłoża choroby, oparte na analizach sprzężeń, wymagały badań przeprowadzanych na materiale pochodzącym od dużych rodzin, $\mathrm{z}$ wieloma osobami chorymi. Rozwój NGS sprawił, że sekwencjonowanie całego genomu lub całego eksomu stało się możliwe w krótkim czasie, co z kolei spowodowało zmianę strategii identyfikacji genów odpowiedzialnych za wystąpienie danego schorzenia.

W ocenie NSHL pogłębione testy genetyczne powinny być wykonywane po zebraniu historii choroby, badaniu fizykalnym, audiometrii oraz wykonaniu analizy genu GJB2. Ustalenie genetycznej przyczyny wystąpienia niedosłuchu jest cenne, ponieważ może wykluczyć konieczność wykonywania dalszych (niejednokrotnie kosztownych i inwazyjnych) badań diagnostycznych, może również pomóc zidentyfikować ewentualne choroby współistniejące i dostarczyć rodzinom, dzięki poradnictwu genetycznemu, cennych informacji prognostycznych. W przyszłości, w dobie medycyny spersonalizowanej, badania genetyczne będą podstawą celowanych terapii molekularnych. W przypadku niemożliwości zdiagnozowania choroby genetycznej jedynie na podstawie obrazu klinicznego pacjenta lub też analizy skrajnie niejednorodnego genetycznie schorzenia, z możliwością wystąpienia do kilkuset genów zaangażowanych w jego patogenezę, istnieją możliwości wykonania szeroko zakrojonych testów genetycznych w celu postawienia precyzyjnej diagnozy. Sekwencjonowanie eksomowe staje się potężnym narzędziem do wykonywania testów przesiewowych w chorobach niejednorodnych etiologicznie, takich jak m.in. niedowidzenie, głuchota, choroby mitochondrialne i zaburzenia ruchowe. Ogromna różnorodność dostępnych platform i testów opartych na technologii sekwencjonowania nowej generacji pozwala na dobranie odpowiedniego testu w zależności od klinicznego obrazu oraz dostępnych środków.

Kluczowe punkty:

- Molekularne badania genetyczne jednoznacznie diagnozują przyczynę utraty słuchu i pozwalają na zaplanowanie dalszego postępowania $\mathrm{z}$ pacjentem.

- Technologie sekwencjonowania nowej generacji przyspieszyły tempo odkrywania genów powiązanych z niedosłuchem i umożliwiły kompleksowe testy genetyczne.

- Diagnostyka genetycznej głuchoty jest istotnym etapem procesu diagnostyczno-terapeutycznego, m.in. z uwagi na możliwość uniknięcia dalszych (również inwazyjnych) badań diagnostycznych. Diagnostyka ta umożliwia także odpowiednie poradnictwo genetyczne i dostarcza cennych informacji prognostycznych.

- W przyszłości, w dobie medycyny spersonalizowanej, kompleksowe badania genetyczne u pacjentów $\mathrm{z}$ niedosłuchem będą pierwszym - po zebraniu wywiadu i wykonaniu badań audiometrycznych - z przeprowadzanych testów oraz będą stanowiły podstawę celowanych terapii molekularnych.

Publikacja powstała w związu z realizacją projektów: Grant NCN: 2011/03/D/NZ5/05592; Grant NCN: 2012/05/N/NZ5/02629; „Zintegrowany system narzędzi do diagnostyki i telerehabilitacji schorzeń narzadów zmysłów (słuchu, wzroku, mowy, równowagi, smaku, powonienia)" wspótfinansowany przez Narodowe Centrum Badań i Rozwoju w ramach Programu STRATEGMED. 


\section{Piśmiennictwo:}

1. Morton CC, Nance WE. Newborn hearing screening: a silent revolution. N Engl J Med, 2006; 354: 2151-64.

2. Shearer AE, Hildebrand MS, Sloan CM, Smith RJ. Deafness in the genomics era. Hear Res, 2011; 282: 1-9.

3. Hilgert N, Smith RJH, Van Camp G. Forty-six genes causing nonsyndromic hearing impairment: which ones should be analyzed in DNA diagnostics? Mutat Res, 2009; 681: 189-96.

4. Kothiyal P, Cox S, Ebert J, Husami A, Kenna MA, Greinwald JH i wsp. High-throughput detection of mutations responsible for childhood hearing loss using resequencing microarrays. BMC Biotechnol, 2010; 10: 10.

5. Rodriguez-Paris J, Pique L, Colen T, Roberson J, Gardner P, Schrijver I. Genotyping with a 198 mutation arrayed primer extension array for hereditary hearing loss: assessment of its diagnostic value for medical practice. PLoS One, 2010; 5: e11804.

6. Shearer AE, DeLuca AP, Hildebrand MS, Taylor KR, Gurrola J II, Scherer S i wsp. Comprehensive genetic testing for hereditary hearing loss using massively parallel sequencing. Proc Natl Acad Sci USA, 2010; 107: 21104-9.

7. Brownstein Z, Friedman LM, Shahin H, Oron-Karni V, Kol N, Abu Rayyan A i wsp. Targeted genomic capture and massively parallel sequencing to identify genes for hereditary hearing loss in Middle Eastern families. Genome Biol, 2011; 12: 89.

8. De Keulenaer S, Hellemans J, Lefever S, Renard JP, De Schrijver J, Van de Voorde H i wsp. Molecular diagnostics for congenital hearing loss including 15 deafness genes using a next generation sequencing platform. BMC Med Genomics, 2012; 5: 17.

9. Lechowicz U, Pollak A, Stawiński P, Mueller-Malesińska M, Płoski R. Genetycznie uwarunkowany niedosłuch - perspektywy i możliwości diagnostyczne $\mathrm{z}$ wykorzystaniem sekwencjonowania nowej generacji. Nowa Audiofonologia, 2013; 2(4): $14-21$.
10. Tang W, Qian D, Ahmad S, Mattox D, Todd NW, Han H i wsp. A low-cost exon capture method suitable for large-scale screening of genetic deafness by the massively-parallel sequencing approach. Genet Test Mol Biomark, 2012; 16: 536-42.

11. Najmabadi H, Hu H, Garshasbi M, Zemojtel T, Abedini SS, Chen $\mathrm{W}$ i wsp. Deep sequencing reveals 50 novel genes for recessive cognitive disorders. Nature, 2011; 478: 57-63.

12. Rauch A, Wieczorek D, Graf E, Wieland T, Endele S, Schwarzmayr $\mathrm{T}$ i wsp. Range of genetic mutations associated with severe non-syndromic sporadic intellectual disability: an exome sequencing study. Lancet, 2012; 380: 1674-82.

13. Fritsche LG, Fleckenstein M, Fiebig BS, Schmitz-Valckenberg S, Bindewald-Wittich A, Keilhauer CN i wsp. A subgroup of age-related macular degeneration is associated with mono-allelic sequence variants in the $A B C A 4$ gene. Invest Ophthalmol Vis Sci, 2012; 53: 2112-8.

14. Zheng QY, Yan D, Ouyang XM, Du LL, Yu H, Chang B i wsp. Digenic inheritance of deafness caused by mutations in genes encoding cadherin 23 and protocadherin 15 in mice and humans. Hum Mol Genet, 2005; 14: 103-11.

15. Kooshavar D, Tabatabaiefar MA, Farrokhi E, Abolhasani M, Noori-Daloii MR, Hashemzadeh-Chaleshtori M. Digenic inheritance in autosomal recessive non-syndromic hearing loss cases carrying GJB2 heterozygote mutations: assessment of GJB4, GJA1, and GJC3. Int J Pediatr Otorhinolaryngol, 2013; 77: 189-93.

16. Kryukov GV, Pennacchio LA, Sunyaev SR. Most rare missense alleles are deleterious in humans: implications for complex disease and association studies. Am J Hum Genet, 2007; 80: 727-39.

17. Neale BM, Rivas MA, Voight BF, Altshuler D, Devlin B, Orho-Melander $\mathrm{M}$ i wsp. Testing for an unusual distribution of rare variants. PLoS Genet, 2011; 7: e1001322.

18. Vona B, Müller T, Nanda I, Neuner C, Hofrichter MA, Schröder J i wsp. Targeted next-generation sequencing of deafness genes in hearing-impaired individuals uncovers informative mutations. Genet Med, 2014; 16(12): 945-53. 